\title{
Inversion Research on Aerodynamic Roughness of Different Underlying Surfaces in Aral Sea Basin
}

\author{
Li Qin ${ }^{1, *}$, Huang Yue ${ }^{2}$, Sang Guoqing ${ }^{1}$ and Bao Anming ${ }^{2}$ \\ ${ }^{1}$ School of Water Conservancy and Environment, Key Laboratory of Water Resources and Environmental Engineering in Universities of \\ Shandong, University of Jinan, Jinan,250022, China \\ ${ }^{2}$ Xinjiang Institute of Ecology and Geography. Chinese Academy of Sciences, Urumqi Xinjiang 830011, China
}

\begin{abstract}
The study of water and heat flux in Aral Sea Basin is a hot topic in the study of water resources in Central Asia. Aerodynamic roughness is the key parameter of inversion. ${ }$ om is retrieved based on NDVI and Albedo simulation and verified by the vegetation height in Central Asia. The results show that the inversion of $z_{\text {om }}$ by this model is basically reasonable. In 2018 , the monthly average value of $z_{\text {om }}$ is about $0.056 \mathrm{~m}$, the vegetation height in Aral Sea Basin is about $0.44 \mathrm{~m}$, and both $z_{\text {om }}$ and vegetation height in space are higher in eastern mountainous areas than in western desert areas.
\end{abstract}

\section{Introduction}

Aerodynamic Roughness $\left(z_{\text {om }}\right.$, Aerodynamic Roughness Length) refers to the fact that when airflow passes through a certain physical boundary, if the flow velocity near the boundary is zero, then the physical boundary is said to be aerodynamically rough, and its size mainly depends on the surface roughness, that is, the distribution of underlying surface types ${ }^{[1]}$. $z_{\text {om }}$ is a key parameter for studying surface water heat flux, and is also a basic parameter for estimating thermodynamic roughness $\left(z_{o h}\right.$ Thermal Roughness Length), additional damping of heat transfer $\left(\mathrm{KB}^{(-1)}\right)$, regional sensible heat flux and latent heat flux. Aral Sea Basin is located in the center of Eurasia. It is a typical arid and semi-arid region with a general lack of water resources ${ }^{[2,3]}$. The surface type in this region is complex. The accurate estimation and verification analysis of $z_{\text {om }}$ can provide a more accurate parameter basis for regional energy balance and remote sensing simulation of surface energy in this region.

\section{Research Area and $z_{o m}$ Inversion Model}

\subsection{Overview of Research Area}

The Aral Sea Basin covers a total area of 1.76 million $\mathrm{km}^{2}$, involving five Central Asian countries and Afghanistan and Iran ${ }^{[2,4]}$. Its geographical division is shown in Figure 1.

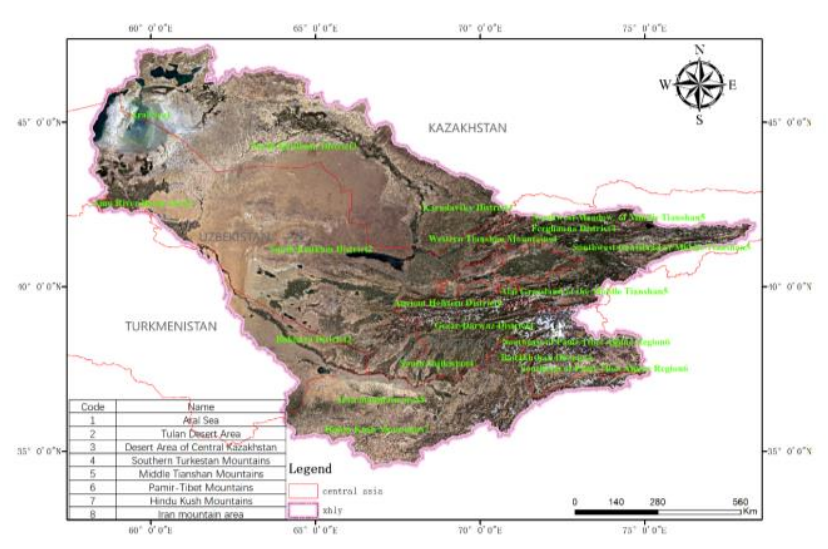

Fig. 1. Aral Sea Basin Geographical Zoning Map

Fig. 1 is a geographic zoning map of the Aral sea basin, including 8 regions and 20 subdistricts, of which 8 regions are: (1) Aral sea; (2) Turan desert area; (3) Central Kazakhstan desert region; (4) Mount South Turkistan region; (5) the high mountain areas of the central Tianshan mountains; (6) Pamir-Tibet high mountain area; (7) Mount Hindu Kush region; (8) Iranian mountainous areas. Aral Sea Basin is a continental climate with typical temperate desert and grassland, with sufficient sunshine and little rain (Han Qifei, 2018; Chen Qichuan, 2012), the annual maximum rainfall is $200 \mathrm{~mm}$, and the annual rainfall in consecutive dry years is $65 \mathrm{~mm}$, and the spatial distribution is uneven. The rainfall in Turan desert area in the southwest of the basin is less than $100 \mathrm{~mm}$. Based on the analysis of the typical vegetation height of each division based on the vegetation division, as shown in Figure 2 and Table 1, the study area is widely distributed in the Haloxylon ammodendron desert area (702), mainly in the Turan desert area. Its typical trees are Haloxylon ammodendron

\footnotetext{
* Corresponding author: stu_liq@ujn.edu.cn
} 
1-7m, shrubs are Calligonum Bai $\mathrm{Pu} 20-150 \mathrm{~cm}$, and typical vegetation in grassland, Gobi and desert is Salix psammophila $14-60 \mathrm{~cm}$. The second is savanna type grass (1012), and the typical vegetation is bulbous barley $70-90 \mathrm{~cm}$; In the desert region of Central Kazakhstan, the vegetation is divided into the central desert Tugailin and meadow (802), with the representative trees being Elaeagnus angustifolia $5-10 \mathrm{~m}$, shrubs being Tamarix ramosissima 3-6m, and herbaceous vegetation being Agropyron strobilacea $80 \mathrm{~cm}$; In addition, there is also Artemisia desert region (705) in the desert region of central Kazakhstan, where shrubs are $8-30 \mathrm{~cm}$ in diameter and herbs are $25-35 \mathrm{~cm}$ in diameter.

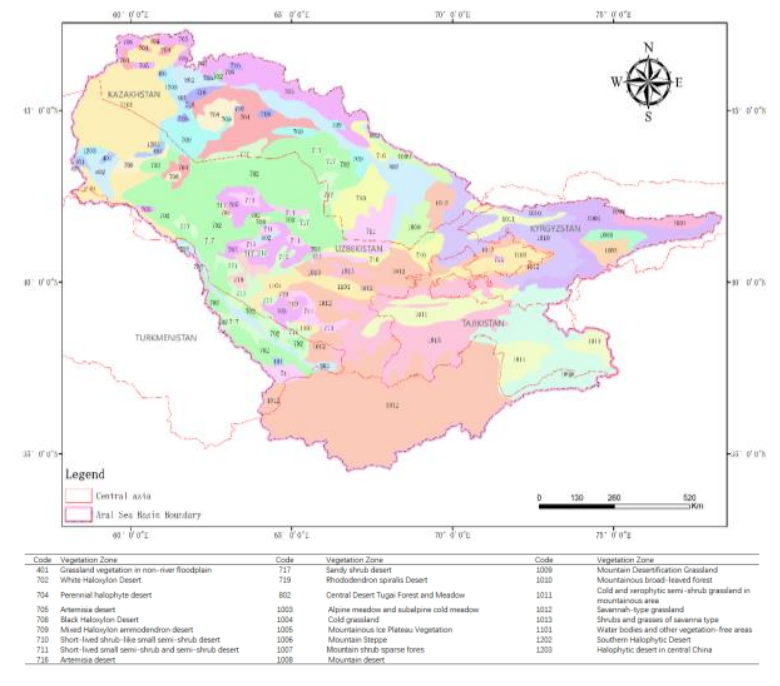

Fig. 2. Aral Sea Basin Vegetation Zoning Map ${ }^{[6]}$

Table 1. Vegetation Zoning in Aral Sea Basin Representing Vegetation Height

\begin{tabular}{|c|c|c|c|c|c|c|c|}
\hline \begin{tabular}{|c|}
$\begin{array}{c}\text { epresentative } \\
\text { plants }\end{array}$ \\
\end{tabular} & Attribute & \begin{tabular}{|l|} 
Vegetation \\
Code \\
\end{tabular} & Height & \begin{tabular}{|c|}
$\begin{array}{c}\text { Representative } \\
\text { plants }\end{array}$ \\
\end{tabular} & Attribute & $\begin{array}{c}\text { Vegetation } \\
\text { Code }\end{array}$ & Height \\
\hline $\begin{array}{l}\text { Halocnemum } \\
\text { strobilaceum }\end{array}$ & \begin{tabular}{|l}
$\begin{array}{l}\text { Perennial semi- } \\
\text { shrub }\end{array}$ \\
\end{tabular} & 401 & $20-40 \mathrm{~cm}$ & Stipa caucasica & Perennial herbs & 1009 & $15-30 \mathrm{~cm}$ \\
\hline \begin{tabular}{|l} 
Common \\
Pistache
\end{tabular} & Small trees & \begin{tabular}{|l|}
1006.1012 .10 \\
13,1101
\end{tabular} & $5-7 \mathrm{~m}$ & \begin{tabular}{|l|}
$\begin{array}{l}\text { Caraganan } \\
\text { aurantiaca } \\
\text { Koehne }\end{array}$ \\
\end{tabular} & Shrub & \begin{tabular}{|l|}
$1006,1010,10$ \\
$11,1012,1013$, \\
1101
\end{tabular} & $\operatorname{lm}$ \\
\hline Festuca coelestis & $\begin{array}{l}\text { Perennial } \\
\text { dense chump }\end{array}$ & $\mid \begin{array}{l}1004,1006,10 \\
08,1010\end{array}$ & 4-15cm & \begin{tabular}{|l|} 
Elytrigia \\
trichophora \\
Nevski.
\end{tabular} & perennial & $\left|\begin{array}{l}1003,1012,10 \\
13,1101\end{array}\right|$ & $50-150 \mathrm{~cm}$ \\
\hline \begin{tabular}{|l|}
$\begin{array}{l}\text { Serighidinm } \\
\text { terrac-albac }\end{array}$ \\
trata
\end{tabular} & $\begin{array}{l}\begin{array}{l}\text { Perennial } \\
\text { subsharub }\end{array} \\
\end{array}$ & $705,708,709$ & $8-30 \mathrm{~cm}$ & $\begin{array}{l}\text { hordeum } \\
\text { bullosumm }\end{array}$ & \begin{tabular}{|l|}
$\begin{array}{l}\text { Perennial } \\
\text { Graminacac }\end{array}$ \\
\end{tabular} & \begin{tabular}{|l|}
1012.1013 .11 \\
01
\end{tabular} & $70-90 \mathrm{~cm}$ \\
\hline \begin{tabular}{|l}
$\begin{array}{l}\text { Zanthoxylum } \\
\text { bungeana }\end{array}$ \\
\end{tabular} & \begin{tabular}{|l}
$\begin{array}{l}\text { Perennial } \\
\text { strubs }\end{array}$ \\
\end{tabular} & 702 & $20-150 \mathrm{~cm}$ & $\begin{array}{l}\text { Calligonum } \\
\text { mongolicum } \\
\text { Turcz. }\end{array}$ & \begin{tabular}{|l}
$\begin{array}{l}\text { Perennial } \\
\text { shrubs }\end{array}$ \\
\end{tabular} & 710.711 & $20-150 \mathrm{~cm}$ \\
\hline $\begin{array}{l}\begin{array}{l}\text { Haloxylon } \\
\text { persicum }\end{array} \\
\end{array}$ & Small trees & 702 & $1-7 \mathrm{~m}$ & \begin{tabular}{|l|}
$\begin{array}{l}\text { Agriophyllum } \\
\text { squarrosum }\end{array}$ \\
\end{tabular} & Annual herbs & 702 & $14-60 \mathrm{~cm}$ \\
\hline Tamarix chinensis & Shrub & 802 & 3-6m & \begin{tabular}{|l|} 
Elaeagnus \\
angustiffolia Limn.
\end{tabular} & Tree & 802 & $5-10 \mathrm{~m}$ \\
\hline $\begin{array}{l}\text { Juniperus } \\
\text { formosana }\end{array}$ & Small trees & 1005,1011 & $12 \mathrm{~m}$ & Prangos Lindl. & & 1003 & $60 \mathrm{~cm}$ \\
\hline \begin{tabular}{|l|} 
Artemisia terrae- \\
abbae
\end{tabular} & \begin{tabular}{|l} 
Biennial herb: \\
perennial shrub
\end{tabular} & 717 & 50-150 & Carex spp. & Perennial herb & $\begin{array}{l}401,702,704,7 \\
05,708,709.71 \\
0,711,1203\end{array}$ & $20 \mathrm{~cm}$ \\
\hline Salsola orientails & Small shrub & 710,711 & $30-35 \mathrm{~cm}$ & $\begin{array}{l}\text { Halocnermum } \\
\text { str. }\end{array}$ & \begin{tabular}{|l}
$\begin{array}{l}\text { Perennial semi- } \\
\text { shrub }\end{array}$ \\
|
\end{tabular} & $\begin{array}{l}704,1202,120 \\
3\end{array}$ & $20-40 \mathrm{~cm}$ \\
\hline \begin{tabular}{|l|}
$\begin{array}{l}\text { Agropyron } \\
\text { crispus }\end{array}$ \\
\end{tabular} & Perennial herbs & $\begin{array}{l}802,1005,101 \\
1\end{array}$ & $80 \mathrm{~cm}$ & Anabasis salsa & \begin{tabular}{|lc}
$\begin{array}{l}\text { Small } \\
\text { shrub }\end{array}$ & half \\
\end{tabular} & $704,717,719$ & $15-20 \mathrm{~cm}$ \\
\hline $\begin{array}{l}\text { Oxytropis } \\
\text { immersa }\end{array}$ & Perennial herbs & 1005,1011 & $20 \mathrm{~cm}$ & Artcmisia Linn. & \begin{tabular}{|l|} 
Peremial herbs \\
or \\
or semi- \\
shrubby. small \\
shrubby plants
\end{tabular} & $1006,1008,10$ & $70 \mathrm{~cm}$ \\
\hline \begin{tabular}{|l} 
Haloxylon \\
aphyllum
\end{tabular} & Small trees & 708,709 & $7-8 \mathrm{~m}$ & Poa pratensis & Annual Grass & 716 & $6-30 \mathrm{~cm}$ \\
\hline Betula & Tree & 1010 & $20 \mathrm{~m}$ & \begin{tabular}{|ll}
$\begin{array}{l}\text { Sipa } \\
\text { Linn }\end{array}$ & capillata \\
\end{tabular} & Perennial heros & $\begin{array}{l}1006,1008,10 \\
10\end{array}$ & $40-80 \mathrm{~cm}$ \\
\hline \begin{tabular}{|l} 
Desert \\
Helilictotichon
\end{tabular} & $\begin{array}{l}\begin{array}{l}\text { Perennial, } \\
\text { xerophytic } \\
\text { grasses }\end{array} \\
\end{array}$ & 1004 & $25-70 \mathrm{~cm}$ & \begin{tabular}{|l} 
Salsolacollina \\
Pall.
\end{tabular} & Annual herbs & 705 & $25-35 \mathrm{~cm}$ \\
\hline $\begin{array}{l}\text { Astragalus } \\
\text { propinquus } \\
\text { Schischkin }\end{array}$ & Perennial herbs & 719 & $10-20 \mathrm{~cm}$ & & & & \\
\hline
\end{tabular}

\section{$2.2 z_{\text {om }}$ and $\mathbf{H}$ Inversion Model}

Currently, $z_{\text {om }}$ is estimated in many ways and mostly by empirical formulas. This paper is based on the empirical formula proposed by Liu ${ }^{[5,7]}$, which can estimate $z_{\text {om }}$ and $\mathrm{H}$ in a large range using remote sensing data as shown in formula (1) (2). The remote sensing image is the 30-day composite daily mean data of MODIS NDVI and albedo $1 \mathrm{~km}$ in 2018. In the simulation process, using the geographical division and vegetation type division of Central Asia ${ }^{[6]}$ and the land cover of Aral Sea basin, the typical representative vegetation maximum height values of each vegetation division in the study area (as shown in Table 1) are obtained and spatially analyzed. It is proposed to compare the simulated values of $\mathrm{H}$ and June, analyzed the applicability and rationality of the empirical formula in Aral Sea region, and revise the inversion results. The vegetation code is shown in Figure 2.

$$
Z_{\text {om }}=\exp \left(a \frac{N D V I}{a}-b\right)
$$

Where, $a$ and $b$ are empirical coefficients, which refers to 0.0553 and 3.64 respectively; $\alpha$ is broad band albedo and NDVI is normalized difference vegetation index.

$$
H=z_{\text {om }} / 0.136
$$

\section{Analysis of Inversion Results}

\subsection{Rationality Analysis of Simulation Results}

The simulated vegetation height in June based on $z_{\text {om }}$ inversion is compared with the spatial distribution map of vegetation height formed by typical vegetation gridding based on vegetation zoning and surface classification, as shown in Table 2, in which the vegetation height is compared and analyzed according to the three conditions of land type, geographical zoning and vegetation zoning respectively, hRe is the height of typical vegetation and hes is the simulated inversion of vegetation height. According to the analysis of land type, the highest simulated result value of forest land for vegetation height is $16.66 \mathrm{~m}$, followed by $2.57 \mathrm{~m}$ for urban land and $2.31 \mathrm{~m}$ for rural residential land. Thirdly, the average height of shrub forest is $1.52 \mathrm{~m}$, and the height of other land types is between 0.5 and 0.02 . Compared with the height of typical vegetation in different regions, the simulated values are smaller in desert, Gobi, saline-alkali land, wetland, dry land, urban land and residential area, while the simulated heights of woodland and shrub are larger. Other simulated values are close to the height of typical vegetation. Based on geographical division, the height of simulated vegetation is higher than that of typical vegetation in Fergana region, Guhrstein region and Gizal-Dalvaz region, while the height of simulated vegetation in other regions is slightly different from that of typical vegetation. The height of simulated vegetation based on vegetation zoning is generally lower than that of typical vegetation 
in the region, with the exception of savannah shrub sparse forest and grass and mountain cold xerophytic subshrub grassland. The average height of simulated vegetation is $1.86 \mathrm{~m}$ and $1.31 \mathrm{~m}$ respectively, and the height of typical vegetation is $1.08 \mathrm{~m}$ and $0.92 \mathrm{~m}$ respectively. By comparing the simulated vegetation height and typical vegetation height of different land types, different geographical divisions and vegetation divisions, the simulated values are generally reasonable.

Table 2. Height Simulation Validation Analysis

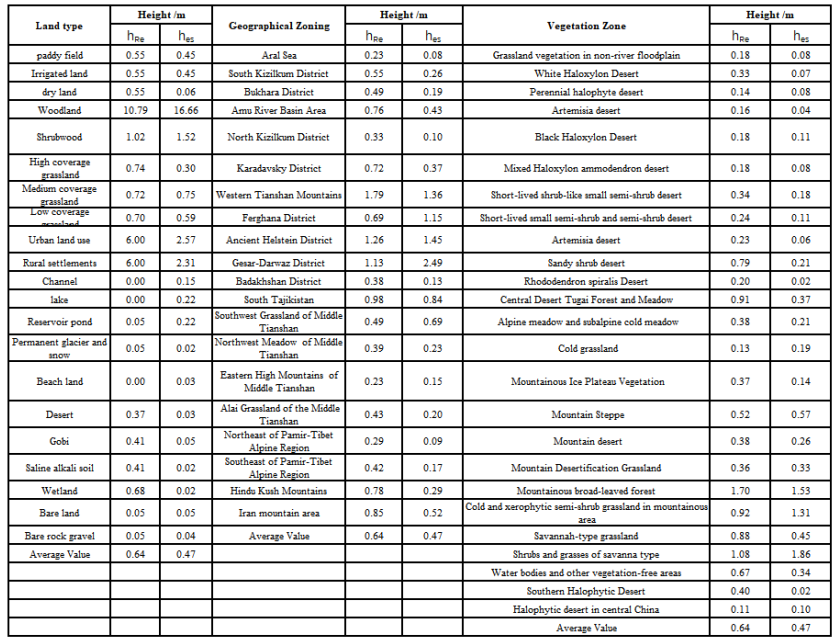

\subsection{The analysis of simulation result}

The analysis of the simulation result is based on the change of the monthly mean value of $z_{\text {om }} 2018$ in different geographical areas as shown in Figure 3 . According to the value, it is divided into 5 grades. The corresponding land types of $0.002 \sim 0.0029 \mathrm{~m}$ include permanent glacier and snow, beach, saline-alkali land, wetland and desert. The maximum $z_{\text {om }}$ of wetland and desert reaches the annual peak value of $0.0028 \mathrm{~m}$ around April, and the $z_{\text {om }}$ of other land types is between $0.0025 \sim 0.0028 \mathrm{~m}$; The corresponding land types of $0.006 \sim 0.013 \mathrm{~m}$ are dry land, lake, Gobi and bare land, among which $z_{\text {om }}$ in dry land rose from $0.0065 \mathrm{~m}$ to $0.0075 \mathrm{~m}$ from March to October. The changes of $z_{\text {om }}$ in bare land, Gobi and lake are not big. $0.15 \sim 0.45 \mathrm{~m}$, bush forest, urban land and rural residential area $z_{\text {om }}$ are $0.20 \mathrm{~m}, 0.40 \mathrm{~m}$ and $0.30 \mathrm{~m}$ respectively; The $z_{\text {om }}$ of paddy field, irrigated land, high coverage grassland, medium coverage grassland, low coverage grassland, canals, reservoir ponds and bare rock gravelly land fluctuates between $0.018 \mathrm{~m}$ and $0.080 \mathrm{~m}$. The $z_{\text {om }}$ value of forested land fluctuates between $1.86 \sim 2.0 \mathrm{~m}$, with the highest month being around June.

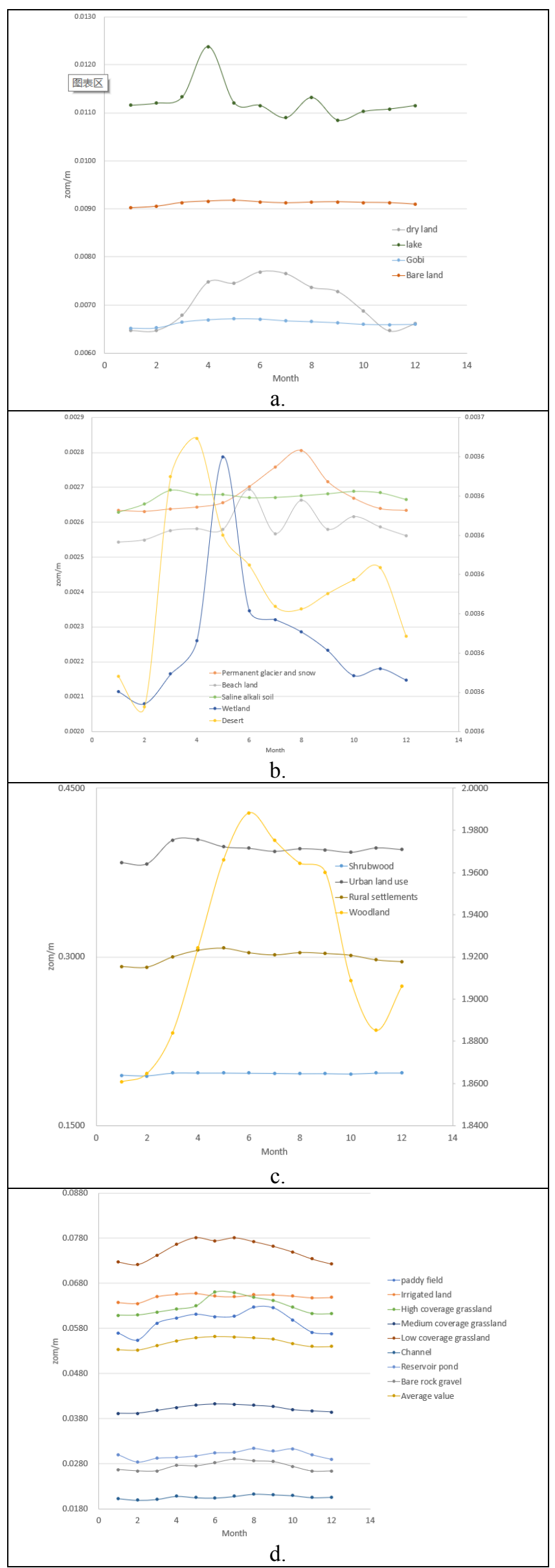

Fig. 3. $z_{\text {om }}$ monthly mean of different land types in 2018 
In Aral sea basin in 2018 is shown in fig. 4. since the floating value of $z_{\text {om }}$ in each month is small, the spatial distribution of $z_{\text {om }}$ is illustrated by taking June 2018 as an example. According to the statistical mean of $z_{\text {om }}$ geographical division at 2000 random points in the study area, the $z_{\text {om }}$ values in the western mountain area, the Alai grassland area in the central Tianshan Mountains and the Gisar-Dalvaz area are about $0.0562 \mathrm{~m}$; Secondly, $z_{\text {om }}$ in guhstein area is $0.1628 \mathrm{~m} ; z_{\text {om }}$ is $0.0965 \mathrm{~m}$ in southwest Tianshan grassland area. The lowest area of $z_{\text {om }}$ is $0.0059 \mathrm{~m}$ in Aral sea and $0.07 \mathrm{~m} \sim 0.01 \mathrm{~m}$ in other areas. From the spatial distribution map of $z_{\text {om }}$, it can be seen that $z_{\text {om }}$ is between 0.001 and $0.003 \mathrm{~m}$ in the north Kizilkum region, the south Kizilkum region and the Aral sea region. The $z_{\text {om }}$ values in the Hindu Kush and Iranian mountains are between 0.03 and $0.05 \mathrm{~m}$; The $z_{\text {om }}$ in the northwestern Amu Darya river basin, the northeastern bukhara region, the southern western Tianshan mountain and the guhstan region is between 0.08 and $0.1 \mathrm{~m}$, and the $z_{\text {om }}$ in the south Turkistan mountain region and the high mountain region of the central Tianshan mountain is between 0.8 and $5.0 \mathrm{~m}$.

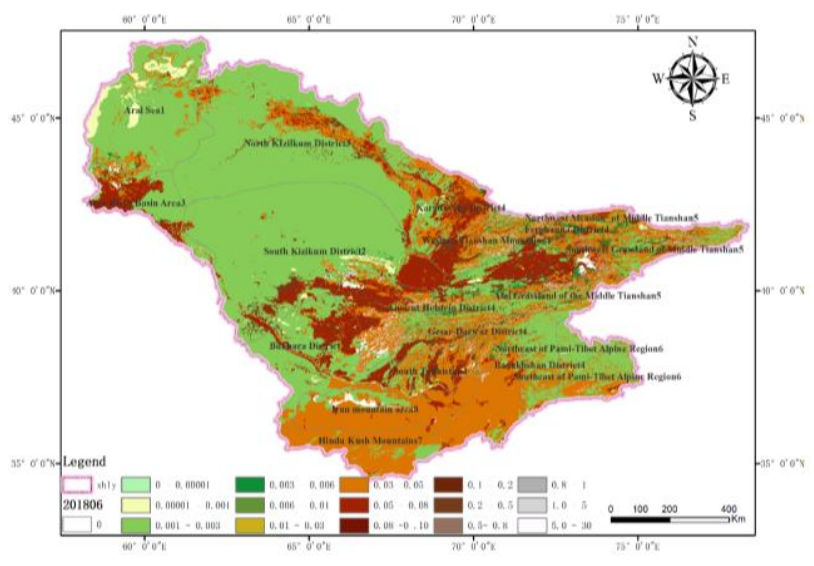

Fig. 4. $z_{\text {om }}$ spatial distribution of different geographical divisions in June 2018

The spatial distribution of Aral Sea Basin H in June 2018 is shown in Figure 5. The H of North Kizilkum Region, South Kizilkum Region and Aral Sea Region is between 0.0001 0.1m; The eastern Aral Sea Basin includes the South Turkistan Mountains and the high mountain areas of the Central Tianshan Mountains. The vegetation height is between 0.3 and $0.5 \mathrm{~m}$. During this period, the vegetation height of some forest lands is scattered between 3 and 3 20m. Based on the analysis of random dotting values in the study area, based on the analysis of land types, the $h$ value of forested land is the highest at $16.66 \mathrm{~m}$, followed by the vegetation height of urban land and rural residential areas at $2.6 \mathrm{~m}$ and $2.3 \mathrm{~m}$, the vegetation height of shrubbery is about $1.5 \mathrm{~m}$ again, the vegetation height of paddy field and irrigated land is about $0.44 \mathrm{~m}$, and the vegetation height of other land types is between 0.01 and $0.8 \mathrm{~m}$. According to geographical division analysis, the vegetation height in Aral Sea region varies from $0.04 \mathrm{~m}$ to $0.08 \mathrm{~m}$. The vegetation height in Guisard-Dalvaz region is about
$2.45 \mathrm{~m}$, followed by Guhestan, West Tianshan and Fergana regions, with vegetation heights of $1.45 \mathrm{~m}$, $1.35 \mathrm{~m}$ and $1.13 \mathrm{~m}$ respectively. The vegetation height in the grassland area in the southwest of Zhongtian is $0.68 \mathrm{~m}$, that in the mountainous area of Iran is $0.50 \mathrm{~m}$, and that in the Amu Darya River Basin is $0.43 \mathrm{~m}$ on average. The vegetation height in other areas fluctuates between $0.08 \sim 0.4 \mathrm{~m}$.

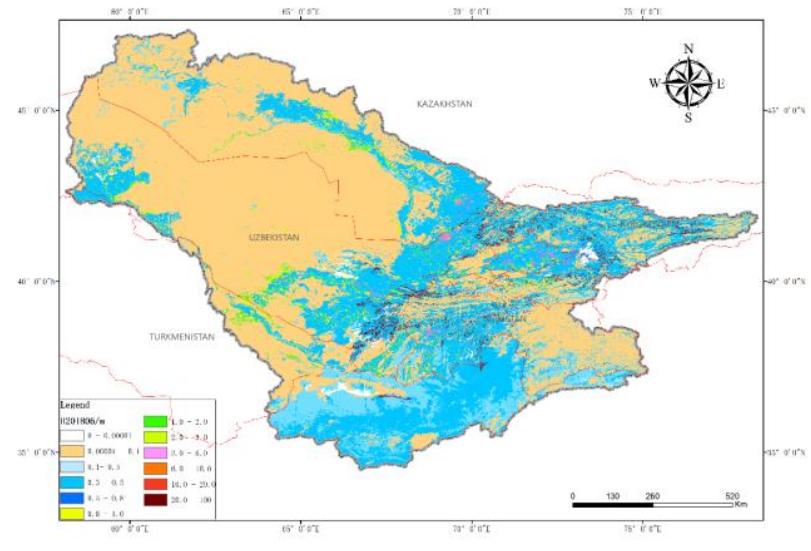

Fig. 5. Simulated spatial distribution map of vegetation height $\mathrm{h}$ of Aral sea basin in June 2018

\section{Conclusion}

The results of dynamic roughness of Aral sea basin based on NDVI and Albedo simulation inversion are reasonable. In 2018, the monthly average value of $z$ om is about $0.056 \mathrm{~m}$, the eastern part is larger than the western part in space, the mountainous area is higher than the plain desert, and the woodland, grassland and town land are larger than other land types, especially the Gobi and desert areas, z_om is about $0.003 \mathrm{~m} \mathrm{~m}$. The vegetation height in Aral Sea Basin is about $0.44 \mathrm{~m} \mathrm{~m}$. According to the comparison of land types, there are woodland $H$ value $>$ urban land $>$ village residential vegetation height $>$ shrub vegetation height $>$ paddy field and irrigated land vegetation height $>$ other land types. According to geographical division comparison, the vegetation height in Guisard-Dalvaz region > Guhstan $>$ west Tianshan region $>$ Fergana region $>$ southwest grassland region of Zhongtian $>$ Iranian mountain region vegetation height is $0.50 \mathrm{~m}>\mathrm{Amu}$ Darya river basin vegetation $>$ other regions, of which the Aral sea region vegetation height changes at the lowest level between 0.04 and $0.08 \mathrm{~m}$.

\section{Acknowledgment}

The study is financially supported by the Opening Fund of Xinjiang Key Laboratory of Remote Sensing and Geography Information System(W2019051), The Provincial water conservancy scientific research Project (SDSLKY201808), the University of Jinan High GF data Application Training Special Project (XKY11744). 


\section{References}

1. J. Yingqin, Study of Aerodynamic Roughness Length and Thermal Roughness Length on different underlying surfaces," Nanjing: Nanjing University, (2012)

2. T. Xiangrong, W. Guoyi, F. Yanfang, Aral Sea Basin Transboundary Water Cooperation: History, Present Situation and Reflections, Journal of Boundary and Ocean Studies, Vol.2, No.6, November,90-104, (2017)

3. H. Qifei, L. Yan, L. Chaofan, Impact of climate change on grassland carbon cycling in Central Asia, Arid Land Geography, Vol.41, No.6, November,1351-1357, (2018)

4. C. Qichuan, X. Ziqiang, G. Lidan, etal., Variation Characteristics and Trend Analysis of Precipitation in Central Asia Zones, Water Resources and Power, Vol.30, No.6, Jun.,13-16, (2012)

5. Y. Xinxiao, J. Guodong, W. Hailong, etal., Ecoevapotranspiration system, Beijing: Science Press. (2018)

6. Z. Yuanming, L. Yaoming, S. Guanmian, etal., Plant Resources And Utilization in Central Asia, Beijing: China Meteorological Press, (2013)

7. C. Xi, Retrieval and Analysis of Evapotranspiration in Central Areas of Asia, Beijing: China Meteorological Press, (2012) 